\title{
Bicultural Development within an Early Childhood Teacher Education Programme
}

\section{Jenny Ritchie}

\begin{abstract}
This paper reports findings from a doctoral study which focused on processes implemented within an early childhood teacher education programme at the University of Waikato in Hamilton, New Zealand, that aimed to deliver on a stated commitment to Te Tiriti o Waitangi/the Treaty of Waitangi. This 1840 treaty guaranteed protection to Māori, the indigenous people of Aotearoa/New Zealand. As a result of the impact of colonisation by Britain, Māori have become marginalised within their own country, and their language is threatened. Recognition of the treaty necessitates a restorative process that may be termed 'bicultural development'. This paper describes key features of the bicultural development process implemented within this teacher education programme.
\end{abstract}

\section{Introduction}

Recognition of the rights of indigenous peoples to retain their language and culture, although enshrined in international covenants (Carr, 1993), is often more problematic when examined at the level of implementation. Education, and even more specifically teacher education, is a key site to introduce innovations which may assist in enhancing progress in this area (Wideen et al., 1998). In 1989, a new 3 year early childhood teacher education qualification was introduced at the former Hamilton Teachers' College, which since amalgamation in 1991 has been the School of Education, University of Waikato. This programme was devised in consultation with the wider early childhood care and education community and had a strong commitment to biculturalism from the outset (Carr et al., 1991). The author has been teaching in this programme since 1990. In 1996, the New Zealand Ministry of Education disseminated the first curriculum for early childhood education in this country, 'Te Whāriki' (Ministry of Education, 1996a), and revised the requirements contained within its 'Statement of Desirable Objectives and Practices' in line with this new curriculum (Ministry of Education, 1996b). Te Whäriki, which was also the first bicultural curriculum for this country, contained strong statements of recognition of the Treaty of Waitangi, and concomitant expectations that teachers would incorporate the Māori language and culture in early childhood education programmes. This served to strengthen the need for teacher educators to prepare graduates committed and competent to deliver on this bicultural obligation.

'Bicultural development' (Metge, 1990, p. 18) is a social change process generated from a commitment to social justice and Te Tiriti o Waitangi/the Treaty of Waitangi. The implication of 'development' is one of an ongoing process of change towards an equitable bicultural society (Metge, 1990). Steps taken within the early childhood teacher education programme at the University of Waikato can be seen as part of a process of bicultural development. 


\section{Methodology}

This study adopted critical pedagogy as its key theoretical domain, and this also informed the methodological approach which aimed at transformative praxis utilising qualitative methodological processes, central to which was a commitment to accountability to participants. Data came from taped interviews and class discussions, observations, an open-ended questionnaire, and samples of student assignments as data. In 1997, interviews were conducted with 18 different participants who included: four Māori colleagues and four Pākehā colleagues from the Department of Early Childhood Studies (Māori are the indigenous people of Aotearoa/New Zealand and Pākehā is a term for New Zealanders of European ancestry); three Māori and three Pākehā graduates from the early childhood programme at the University of Waikato; and another group of participants who were working as facilitators of professional development for early childhood centres (one Pākehā and three Māori). Additional data came from two university classes, in a level two paper, 1058.213B, Cultural Studies Two, taped in 1997 and 1998, observations of 13 different early childhood programmes undertaken in 1999, and a written survey, conducted in the year 2000, of graduates of the early childhood degree programme ( 28 responses received).

\section{Lecturers' Aspirations}

Two aspects were identified as being central to the preparation of early childhood teachers in terms of their preparedness to deliver early childhood programmes that have a focus on bicultural development. The first was seen as the goal of generating in Pākehā and Tauiwi (Tauiwi refers to non-Māori, such as Pacific Island or Asian) students a 'heartfelt' commitment to the notion of bicultural development. Secondly, Māori colleagues, in particular, were concerned to ensure that teachers who were being released from the teacher education programme were well prepared in terms of having learnt to critique and counter racism, as well as being competent to find ways to deliver Māori content responsively and appropriately.

The idea of 'fostering people's bicultural development' was salient in interviews with two Pākehā colleagues. One described the idea of generating a heartfelt commitment, which became a recurrent theme during the study. This colleague provided valuable insight into this process of 'creating heart', or commitment to bicultural development, and which she person-ally considered to be a moral imperative. Strategies she identified for generating in students an understanding of and commitment to bicultural development included:

- the importance of generating a receptivity to bicultural development early in the programme, and also to avoid a feeling of 'compulsion';

- recognising that offering a range of different approaches increases the likelihood of reaching a greater range of students;

- the importance of students accessing factual information;

- the need for care in regard to the emotional impact on students of learning about the injustices of the past;

- the recognition that for some students a useful framework is the concept of partnership and respectful relationships. 
The idea of heartfelt commitment being of central importance was reinforced by comments from Pākehā graduates:

Yes, a lot of it is knowledge I think, but a lot is in your heart sort of thing. It is because I want to understand Māori people and I have been given the knowledge to understand about injustices. (GP1)

If you haven't got the commitment to actually implement something and feel the, you know, the heart to do it, then it is one of the hardest things. (GP3)

This points to the purpose of the teacher education programme as being much wider and deeper than one of a mechanical, technical process of preparing teachers with the requisite skills. The extent of bicultural competence achieved by student teachers is immaterial if they lack the commitment to pursue bicultural development in early childhood centres. It also raises questions as to the ways and means of establishing this 'heartfelt' commitment.

Recognising the ignorance regarding te ao Māori (the Māori world), and latent racism within the wider New Zealand society, bicultural development was seen by Māori colleagues to be a key strategy in preparing incoming students to be 'culturally safe' (Ramsden \& Spoonley, 1993; Ramsden, 1994a) in their future work with tamariki (children) and whānau Māori (Māori families):

... many of the new students in the auraki [mainstream] intake pose a possible threat to these children and their whānau not to mention non-Māori. If this is my criticism of these students I also believe it is our duty to make sure that these people are safe by the time they are ready to leave us. Māori content in courses is one strategy of breaking down these barriers. (CM2)

The term 'cultural safety' derives from the work of Irihapeti Ramsden in the area of nurse education (Ramsden \& Spoonley, 1993; Ramsden, 1994a, b). Cultural safety practice requires educational provision which generates 'a profound understanding of the history and social function of racism and the colonial process' and 'a critical analysis of existing social, political and cultural structures and the physical, mental, spiritual and social outcomes for people who are different' (Ramsden, 1994a, p. 23). It is also 'designed to create emancipatory change' (Ramsden, 1994a, p. 23).

Māori colleagues recognised that although many Māori children do not attend kōhanga reo (a Māori language development movement which focuses on young children) or other Māori immersion early childhood centres, this does not indicate a lack of concern on the part of their whānau (families) for their Māori culture and identity. Research has demonstrated that Māori families still place a high emphasis on their children learning and speaking te reo (Māori language) (AGB/McNair, 1992; Else, 1997; Te Puni Kōkiri/Ministry of Māori Development, 1998a, b; Durie, 2001). Māori lecturers in the programme saw their role to be one of contributing to improving the quality of this provision for tamariki in mainstream early childhood centres.

\section{Pedagogical Approaches}

Some pedagogical approaches implemented within the Department of Early Childhood Studies at the University of Waikato, included the compulsory introductory Tiriti and Anti-racism workshop; interactive teaching which encourages 
critical reflection; integration of theory and practice; and employing strategies which recognise the role of emotions in learning, particularly learning which involves critique of one's own values and beliefs.

\section{Introductory Workshop: Te Tiriti and History of Colonisation, Cultural and Racism Awareness}

A Pākehā colleague saw value in the early positioning of the compulsory introductory Tiriti workshops which provide students with information on the background to the signing of Te Tiriti, the colonisation which followed, and an exploration of issues of racism:

I think that what we do right from the beginning of our programme in terms of the Treaty courses, puts the bicultural stuff in the place which is a very important starting point ... so most students from that very point are ready to look at what it means to be working biculturally to start with, and then to be transferring across some of the principles that they're talking about and that they're working with. (CP1)

Another of the Pākehā lecturers explained the need for generating a baseline understanding that would be a platform for bicultural development:

One of the things that I believe very strongly is that if you are going to have bicultural issues as an integral theme that is running right throughout the courses then ... it's really setting people up for ... failure if you don't give people a thorough understanding, because people come with misconceptions about what bicultural development is, they come with fears and hostilities and stuff. They come with ignorance basically, lack of knowledge and misinformation that they have got from all over the place. And, therefore, if you are saying 'Okay now in all these classes we are going to look at Māori content', Māori perspectives in the music class or whatever, people will switch off from that and will not learn it unless they have a philosophical understanding of why that's important, and also if they don't have an understanding of it being a 'win-win' situation I guess. I think a lot ... of Pākehā think that... if Pākehā give, ... if we give an inch we will lose. Māori will take. And I think that to me it is really important to realise that whole thing of diversity is ... there is richness in diversity, that it will be a win-win situation ... Before you can look at colonisation and childrearing you have got to have a basic understanding of colonisation before you look at specifics of it. (CP2)

The benefit of the introductory workshops was also mentioned by Pākehā graduates. One commented:

I mean like the courses that we did in the first introduction blocks about the Treaty of Waitangi and different bicultural issues and things like that, it sort of made a lot of people open their eyes. (GP3)

Henry Giroux has described how history can become 'hardened into a form of social amnesia' through 'a mode of consciousness that "forgets" its own development' (Giroux, 1983, p. 39). In Aotearoa/New Zealand, the writer Maurice Shadbolt has identified a national syndrome of historical amnesia which may previously have been associated with a deep-seated guilt or unwillingness to acknowledge the tensions and treachery of our past (Shadbolt, 1999, p. 40). Students need opportunities to recover the history of this country in order to contextualise their contemporary understandings (Siraj-Blatchford \& Siraj-Blatchford, 1999, p. 137). A component of this is a solid understanding of the background to the treaty signing, the wording of the two versions (Māori and English), the government policies which subsequently breached the treaty guarantees, and its contemporary relevance as a moral and ethical framework for 
education in Aotearoa/New Zealand. This provides the foundation necessary to translate a commitment to Te Tiriti o Waitangi into practice in early childhood centres, as required by Te Whāriki.

\title{
Interactive Teaching and Praxis
}

Lecturers favoured interactive, workshop-style classes. A Māori colleague saw her role as being a prepared problem poser:

Generally, I like the students to find information for themselves ... My job is also to have a sound knowledge of the content and to provide a clear indication of what information needs to be sought when working together on readings, viewing a video or listening to speakers ... My job is also to pose questions in order to generate critical thinking and to keep everyone on the kaupapa [philosophical framework]. Many times clarification is sought from students, so knowing the content is really important when students find themselves in a tight spot. Preparation and planning are fundamental to effective delivery. (CM2)

A Pākehā colleague also described an interactive teaching approach:

\begin{abstract}
...so I try to refer to readings ... where students are able to more appreciate that the way that you interact on a personal basis is not necessarily going to be appropriate in another culture and that there can be huge cultural differences, and to try and increase their awareness of that - that's mostly through readings, and discussion of individual experiences. I think for most of the classes that I run I try as much as possible to run things in a reasonably practical interactive way, because I like that way of teaching, anyway. Some students who are expecting lectures get a bit sort of hōha [annoyed] with it I suppose — role plays ... (CP1)
\end{abstract}

These descriptions share features with Freirean ideals of problem posing and critical analysis, and rigour on the part of the educator (Freire \& Shor, 1987). They are also consistent with paradigms of practical inquiry and critical praxis which focus on concrete problem solving in specific situations with the goal of increasing the students' ability to respond proactively within their future teaching situations (Lubeck, 1996, p. 162).

\section{Integration of Theory and Practice}

A key focus of the programme is the integration of theory and practice. The programme attempts to provide opportunities for the 'theory' of bicultural development to be applied during practicum experiences. Māori colleagues were critical of the standards of te reo being demonstrated by students on practicum, but were reluctant to lower the required competencies. This indicates that more preparation is required by students.

Over the 3 years of the degree programme, students experience a range of different early childhood settings and programmes, many of which may not provide strong models of bicultural development. This creates tension for students, which is acknowledged and explored through written requirements such as reflective journals, individual practicum 'de-briefings' and class discussions (Zeichner et al., 1998). Examples of students' reflections on practicum indicate that even though in many early childhood students the competencies required are beyond what is current practice in that centre, as students persist in their implementation they are rewarded 
with positive responses from children. A student recorded these changes over a year 3 practicum, as shown in the following excerpts:

\section{WEEK TWO}

Kept on using the singular words. Had a better response this week from the children ... I spent about quarter of an hour with two morning children teaching them the te reo [Māori language] numbers. The response from their learning was great. They really felt like they had learnt something and felt very proud of themselves. I checked with them later in the session to see if they still remembered them and they did. So that was really great ...

WEEK SIX

It is so neat to see the children using te reo and gradually picking it up and integrating it into other curriculum and play areas themselves. So this week has been really neat and rewarding for us as staff to see the breakthrough with the children. (SWY3P8)

This progression in which the student has persisted in her implementation of Māori language with increasingly positive reactions from the children is fairly typical of those that students have documented in their practicum records. It demonstrates the praxis of students implement-ing bicultural development in their teaching practice.

\section{Validating Emotions}

A Pākehā colleague described the emotions of her own process of becoming committed to honouring Te Tiriti o Waitangi as she learned of past injustices perpetrated on Māori

That was very much for me, that the injustice of it, the wrongness of it, caused grief and that was terrible and it didn't really matter what the facts were-do you know what I mean. The accurate historical stuff was kind of an irrelevance because people were in pain and that needed to be changed and that was very much I guess what impacted on me. (CP2)

This colleague emphasised the importance of recognising and responding sensitively to students' emotional reactions. Māori colleagues were also aware that working with non-Māori students to generate a receptivity towards Māori language and culture involves an awareness of this emotional component:

I think a lot of Pākehā students really want to know, but a lot of them are scared. They are afraid of saying or doing the wrong thing ... (CM4)

Venturing into uncharted learning territory involves a fear of the unknown (Daloz, 1990). In terms of attempting to learn te reo, the second language acquisition literature provides some insight into emotional aspects. Crawford describes the 'affective filter, a term for all the emotional barriers which may impede the second language learning process, including low motivation to learn the language, and a fear of sounding foolish' (Crawford, 1992, p. 212).

According to hooks, lecturers need to have compassion for the pain that may arise for students in giving up old ways of thinking and knowing and learning new approaches (hooks, 1994, pp. 42-43). One of the Māori participants was clear that it was very important that non-Māori students were exposed to positive experiences and role models (MPH4). A Māori colleague used the term 'mentor' to describe her role in supporting non-Māori students, and considered this the most important strategy in supporting their change process: 
It was really important to have a mentor that she could sort of touch base with and just confirm things like, you know how we were saying, some people have a fear of entering into that arena because of the mistakes, so having a mentor that was the biggest factor ... Because we talk about, if you are going to move in this direction, we talked about we all need a kaitiaki [guardian or care-giver] to move us along this pathway. That was a pivotal factor. And of course being able to make the mistakes. I always say, 'Hey, while we are here, let's make those mistakes and feel okay about it. No one is going to jump down you ... Let's try it out and when you get out there and you need to come back and touch base that's okay'. (MPH3)

Lecturers can also model our emotional engagement with the world, through sharing our experiences and passions, talking about our feelings, and generating a shared sense of humanity, enjoyment and humour (Freire \& Shor, 1987; R. Simon, 1992). As a Pākehā graduate said of bicultural experiences within the teacher education programme, 'I mean it should be an enjoyable experience' (GP3).

\section{Programme Content: positioning Māori knowledge as central}

The following sections outline some of the issues surrounding the commitment to including Māori perspectives within courses taught by the Department of Early Childhood Studies within the teacher education programme. Paralleling Māori and Western knowledges also makes way for the validation of other worldviews, decentring Western understandings from the positioning which has allowed them to assume the status of (mis)representing universalistic truths.

\section{'Making Māori Things Real'}

One of the Māori colleagues used the phrase 'Making Māori things real', which reflects the goal of paralleling Māori knowledge with Western knowledge within the content of the early childhood teacher education programme. Not only does this validate Māori epistemologies/mātauranga Māori, but it also allows for a relativistic comparison and critique of positivistic, ethnocentric views by positioning Western knowledge as only one knowledge base or worldview alongside many others. This idea was raised at the co-theorising hui, where one of the participants stated, 'It's about recognising the academia in Māori ways of knowing and being ...' (MPH5). This participant continued to explain that:

It's actually seeing Māori children, not as where the deficit is, 'Oh Māori because they don't have this and they don't have that' ... I'm saying, you know, 'Shift your thinking, it's actually about where you place your thinking', because our kids actually carry two sets of knowledge ... (MPH5)

What this participant has highlighted is that, in addition to generating an understanding of different worldviews, this process of paralleling of Māori and Western knowledge bases will enable students to recognise the bicultural paradigm that Māori children and families draw upon as an asset.

Recent developments in the area of evaluating early childhood programmes in the early childhood sector in Aotearoa/New Zealand (Podmore et al., 1998) follow a Learning and Teaching Story Framework, which uses a 'child's voice' to ask questions based on the Te Whäriki strands: 
- How do you appreciate and understand my interests and abilities and those of my family?

- How do you meet my daily needs with care and sensitive consideration?

- How do you engage my mind, offer challenges, and extend my world?

- How do you invite me to listen and communicate, and respond to my own particular efforts?

- How do you encourage and facilitate my endeavours to be part of the wider group? (Podmore et al., 1998, p. v).

In order to answer these questions for a Māori child, the teacher requires an understanding of that child as a Mãori person, embedded in a different worldview from that of the dominant mainstream Pākehā /Western modality that serves as the 'norm' and has such 'normalising' power. Seeing Māori children as bicultural and often bilingual is a repositioning that validates their knowledge, in contrast to 'deficit' views of Māori and other 'minority' children that have been critiqued by Judith Simon and others (Jones et al., 1990; J. Simon, 1992; Coxon et al., 1994; Smith, 1999).

This model, which parallels Māori and Pākehā /Western perspectives, challenges not only the assumption of superiority of Western knowledge but also the positivist view that there are truths and universal theories that Western science has identified for us all to assimilate. As the Siraj-Blatchfords have stated, 'What is at stake is the canon itself' (Siraj-Blatchford \& Siraj-Blatchford, 1999, p. 136). This dual-epistemological model is consistent with calls to bring the knowledge bases of other cultures from the margin to the centre of the curriculum, an approach James Banks has termed 'transformative' (Banks, 1996, p. 339).

This decentring of the Western canon is also a strategic way of encouraging students' critical and reflective capacities. Along with consideration of Māori perspectives on a particular topic, further contrasts can be offered which demonstrate that there is no fixed set of universal Western knowledge but that, instead, 'the cultural archive of the West represents multiple traditions of knowledge', and is not in fact 'a cohesive system of people, practices, values and languages' (Smith, 1999, p. 44).

\section{Inclusion of Cultural Diversity}

Models of multiculturalism and cultural diversity can be used as a means to obfuscate the obligation to Māori contained within the treaty which recognised their status as tangata whenua (people of the land) (Smith, 1986; Sullivan, 1993; Ramsden, 1994b). A Māori participant explained her view of bicultural and multicultural positionings:

PDFM1: I have to endorse the bicultural kaupapa, and I do totally, because I don't believe it excludes a multicultural perspective, I think it embraces ...

JR: ... so that when we are talking about bicultural we are not talking about just purely Pākehā and Māori

PDFM1: No, we are talking about all our wider whānau [family-used here as an inclusive term]. Because they are descendants of the Crown.

JR: They have come in on the Crown immigration policies. PDFM1: That's an inclusive model. 
The model that we have been using in the department is one that is Tiriti based and inclusive of the cultural diversity represented on the Pākehā and Tauiwi side of the treaty partnership. Recognising that respecting Māori aspirations can happen in tandem with affirmation of cultural diversity - that the two ideas are mutually conducive - is a useful paradigm. It is in contrast to tokenistic attempts at 'multiculturalism' which position Māori with other non-Pākehā 'ethnic minorities' at the margins of the dominant mainstream.

\section{Exploring Cultural Values}

Fundamental to growing in one's ability to understand different ways of viewing the world is to come to see one's own cultural perspective as one of many, all of which are equally valid. Cultural differences come to be viewed as important to be recognised and responded to, and this cultural recognition and validation or 'confirmation' (Noddings, 1994, pp. 177-178) can be seen as a fundamental task for any teacher.

\section{Recognising One's Own Cultural Paradigm}

Integral to the decentring of the dominant monocultural Western canon and the development of a reflective, critical analysis of cultural and educational issues, is the process of facilitating Pākehā to explore their own culture and values. One of the Māori graduates described how the Māori students in her intake had supported Pākehā classmates around these issues:

GM2: So we saw our role as being to coax them through the process or help them understand and we did that as much as possible.

JR: How would you do that? Just by talking with them?

GM2: By talking about the issues. Also taking on board the issues like respecting what they had to say and probably advising them to come from their perspective rather than try and come from a Māori perspective. So I think that bonding that we had [within the Māori issues course] was helpful not only to us but also to our Pākehā colleagues.

Interestingly, these Māori students, in encouraging their Pākehā classmates to recognise the validity of their Pākehā cultural perspective, demonstrate that Māori , as bicultural people, have no difficulty understanding 'Pākehā' culture as an entity, and consider it to be the appropriate identity framework for Pākehā.

The following example is from a class discussion regarding values changing between generations:

Student: But what about that time thing. I think in a way we're still trying to come around to their thinking, because I know with my grandparents, I was saying, 'Oh, going to do this at such and such time in the future', and they said 'Why don't you just live for today, you might not be here tomorrow?' JR: Oh really. Student: You know, live for the day. (CS2, 98)

This discussion arose from reflections on Australian aboriginals' very different time orientation, as reported in a course reading (Harris, 1990). The reading is chosen deliberately because the values described are such an extreme contrast to Western values. The intention is that this will ameliorate the tendency some Pākehā students have demonstrated, of inclining to overemphasise commonalities between ours and other cultures, in an attempt to see us as 'all one people'. This can be seen as an 
assimilationist, normalising tendency which, however well intentioned (Delpit, 1988, p. 285; J. Simon, 1992), serves only to deny the existence of very real differences between ours and other cultures' value systems. This denial of Māori children's Māoriness is in effect a denial of their right to a positive identity as Māori .

Furthermore, it serves to reinforce Pākehā ethnocentrism and affirm Pākehā cultural dominance, whilst creating an inequitable situation in which Māori children are constantly being judged by Pākehā /Western standards (J. Simon, 1992, pp. 40-41).

\section{Appreciating Cultural Differences}

During an interview with a Māori graduate, I had been intrigued by her description of how she would encourage Pākehā students to recognise that Māori children were culturally different from Pākehā, and the pedagogical implications of this:

Because I do believe, and I did believe at that time that Māori children are sensory children and that's why they are so different to Pākehā children so coming from that line of thought, I use that quite a lot. And it was quite a learning for my Pākehā colleagues I think because they hadn't seen a child from that, or hadn't seen a Māori child from that perspective that they are sensory children. So I'd role-play what a Māori child was like. They'd have to touch and look under there and those types of things and then my Pākehā colleagues would say, 'Oh yeah they do!' ... (GM2)

This view that Māori children are 'sensory' is supported by Ian Cormack, who writes that:

Creating an effective learning environment for Māori students should mean that visual, auditory, haptic, and kinesthetic learning styles are all acceptable in our classrooms, they should all be catered for. (Cormack, 1997, p. 169)

This position is supported by research studies conducted with indigenous peoples that consistently indicate that indigenous children are 'more successful in processing visual and spatial information than they are in dealing with verbal stimulation' (Ryan, 1992, p. 166). Research further indicates that indigenous children 'should be exposed to a wide variety of instructional strategies' which 'take advantage of student strengths, while at the same time, equipping students with knowledge and skills that would increase their life chances' (Ryan, 1992, p. 168).

\section{Avoiding Stereotypes}

Cultural images lend themselves to stereotyping, which is often associated with racism and consequent negative outcomes for those who have been stereotyped. Robin Lakoff (1990) has explained, that:

People have a great intellectual need to categorize. The world is a chaotic and complicated place. If we saw every thing and every person in it as unique, we could not develop predictions or generalizations about the right way to respond in each of the many situations we encounter. We could not make sense of our universe: making sense depends significantly on forming appropriate and useful categories and making proper assignments to them. But that necessary tendency also makes it possible for the propagandist to suggest false and damaging categorizations that, if artfully presented to a willing hearer, can seem to make sense ... And when the intellectual pleasure and relief at finding a usable generalization connects with the emotional solace of becoming a member of a larger group (us together, us against them), the power of the categorization to mold attitudes and affect behavior is truly awesome and often terrifying. (Lakoff, 1990, pp. 180-181) 
A counter to this tendency to stereotype is to encourage students to be open-minded towards and respectful of different worldviews. Jerome Bruner describes openmindedness as 'a willingness to construe knowledge and values from multiple perspectives without loss of commitment to one's own values' (Bruner, 1990, p. 30). During class discussions, students demonstrated an awareness and avoidance of stereotyping:

Student 1: You have to remember that if you've got say a group of Indian children that they're all different as well. You can't class them as the same. (CS2, 97)

Student 1: I was thinking of another one ... not judging them by their colour, like sometimes you can say ... all of that culture over there you just sort of assume that it's one culture and think oh, yeah, their beliefs are that ... because they actually can be all totally different. JR: Good. Good point.

Student 2: Skin colour isn't a very good judge of culture anyway. (CS2, 97)

These students have indicated that they are able to recognise and critique totalising tendencies that seek the false security offered by the seductive ideal of commonality (MacNaughton, 1998, p. 7).

A participant suggested that respect and understanding generated towards Māori worldviews might transfer to others as students encountered children and families from various cultural backgrounds:

I suppose if you develop the skills of appreciating differences more, that is not so much a skill as an attitude of appreciating things Māori do and the things they hold dear, you must be developing sensitivity to another culture. One would think then that it would open up your way of thinking about other cultures and groups. (PDFP1)

One of the recent graduates surveyed made a comment that endorses this speculation:

I feel I am much more aware of cultural issues. I would have liked to learn more of other cultures, but what I have learnt in a bicultural context will help lead to understanding in a multicultural context. I feel I have the basics I now need to apply them and learn from there. (RG10)

This view is supported by one of the Pākehā lecturers, who considered that her own appreciation of things Māori had contributed to a decrease in her racism towards other cultures:

I guess, I think, I can only come from a personal statement - that by understanding Māori and through the commitment to that culture that I have had much more understanding for Asian and far less racist as far as other cultures go. (CP4)

\section{Cultural Identity as Central}

A Māori graduate of our teacher education programme, now working in a kōhanga reo stated:

Being able to include the child's language and culture into our programme empowers the child to be given the opportunity to develop skills, knowledge in an environment that is similar to her/his home and wider community. It has assisted me in developing strategies to: provide the child with learning experiences that are meaningful; ensuring parents and their whānau feel welcomed and comfortable to participate within the kōhanga reo. (PG11) 
Since culture 'determines different styles of learning and thinking' (Carr, 1993, p. 2), a key responsibility of educators is to make the connections with each child's cultural paradigm.

\section{Partnership Models}

The term 'partnership model' was one suggested by both Māori and Pākehā colleagues as a preferred way of operating, here explained by a Māori colleague:

For me I quite often had thought that it would be really neat that if there could always be two people doing a course and it goes parallel for anything that you are doing, but then there would be all the constraints of money to be able to do that. I mean Māori people are just such a precious resource now. (CM1)

Pākehā colleagues had described various partnership approaches. One preferred to involve Māori colleagues or Māori guest lecturers to teach the Māori content within her courses. Another described a course in which the Māori and Pākehā lecturers cotaught the first four principal lectures of the course, in a more collaborative fashion, introducing material from both Māori and Western perspectives. This teaching was reinforced by providing readings that offered parallel Māori perspectives to the Western material, and also supported by contributions from Māori students within the class. When Pākehā lecturers were making use of literature from Māori sources, they were careful to check the appropriateness of Māori material with Māori colleagues, as a Māori colleague confirmed:

Between staff and all of that, they were conscious about this and they will ask and say who would be good in this and readings and so on, there's been a bit of that going on for the content of different courses. (CM3)

Recognising that Māori staff should be responsible for teaching Māori content, and admitting their own lack of bicultural knowledge and competence, Pākehā staff were sensitive to the issue of Māori control of Māori knowledge:

I think I've tried to hold onto the fact that I'm privileged to have, or to be given, any information, that is really the right of Māori to have, and tried to be sensitive in what I do with that, even though I probably don't always get it right. (CP1)

Partnership models can involve varying means of collaboration, from one where the Māori and Pākehā colleagues work hand in hand to determine content, pedagogy and assessment, to ones where Māori are brought in to do a self-contained section on Māori perspectives.

Parallel teaching models, which enable Māori students to be taught by Māori staff separately from the mainstream group, are utilised in the programme, in the introductory treaty workshop discussed above. These are particularly appropriate when dealing with issues of colonisation (Mikaere, 1998; Consedine \& Consedine, 2001; Jenkins \& Pihama, 2001). Creating these separate spaces for Māori students allows for the repositioning of Māori perspectives as central, creating a 'normalising' effect for Māori experiences, which reduces whakamā (a strong sense of shame) and enables them to express their questions and engage more fully with the material (Jenkins \& Pihama, 2001). 


\title{
Recognising Pākehā Students’' Resistance
}

Another consideration with partnership models is that of determining which content is in fact a Pākehā responsibility. Māori colleagues described as 'draining' the experience of resistance from Pākehā students:

\begin{abstract}
It is draining for one person to cover that. I quite often find that when there is only resistance or the negative stuff comes about I think they pour it out on the Māori tutor and it is often at that time that they actually have to hear a non-Māori saying the same things and they accept them. Just leaving it to Māori just to get those messages - they need to hear it coming from other sources to reinforce that and confirm for them, 'Yes this is the way'. (CM3)
\end{abstract}

She was clear that students were the products of a community and education system that had not provided them with the requisite knowledge and attitudes that would have created a more positive and receptive disposition towards the taonga of te reo and tikanga (highly valued treasures that are the Māori language and culture):

And that's the hard part because people don't know the background to all those issues and sometimes the resistance is related to that outside influence. (CM3)

These views correspond with those related by Ani Mikaere (1998) which arose from her experiences lecturing within the Law School at the University of Waikato, when Pākehā students had complained to the media about the Māori content of a course. Mikaere describes how she and other Māori lecturers felt uncomfortable dealing with Pākehā anger and guilt:

...I felt that I was being held partly responsible for the guilt of Pākehā students at being told the truth about how they had come to hold power in Aotearoa. I considered that to be extraordinarily unfair. Because I am Māori, Pākehā power is my problem. The fact that the monocultural education system has failed to inform Pākehā about the brutality of colonisation becomes my problem, for it is left to me to tell them. (Mikaere, 1998, p. 9)

The indications are that it is more appropriate for Pākehā lecturers to be positioned as responsible for encouraging Pākehā students to examine their own backgrounds and identify the interpretative frameworks which filter and colour their understandings and receptivities. Certainly, dealing with issues such as racism requires a climate of safety for participants. Pākehā feel more comfortable in addressing their own racism when the discussion is facilitated by a Pākehā lecturer who can use personal examples and model her/his own strategies for self-monitoring of assumptions and interpretations. It is possible to structure courses to ensure that Pākehā lecturers can tutor classes in which issues such as racism are to be discussed, enabling Pākehā to exercise leadership in modelling a countering approach, and avoiding the potential for Māori lecturers to be exposed to hostility.

\section{Conclusion}

Generating commitment to bicultural issues and competency in te reo and tikanga were key aspects identified by lecturers as goals for their work with students in the mainstream early childhood teacher education programme at the University of Waikato. Pedagogical strategies consistent with critical pedagogy which recognise the need for interactive dialogical workshop-style teaching, where attitudes and emotions are respected, and individual students are mentored through their change processes, are a central feature described by colleagues within the teacher education programme. 
Partnership between Māori and Pākehā lecturers can ensure that Māori content is taught appropriately, positioned alongside Western content within courses, and that Pākehā lecturers take responsibility for assisting Pākehā students to recognise their historicity of racism and positioning as members of the dominant and colonialist culture. Culture is recognised as a central feature of any educational interaction. Developing cultural awareness becomes a matter of respectful critique, whereby students are offered frameworks which enable them to recognise that their worldview is only one of many, despite the tendency for Western perspectives to assume the status of 'normal' with the consequent 'othering' of non-Western cultural perspectives. Through practical measures such as the steps in a process of bicultural development identified in this study, it is hoped that Māori children and their families will be provided with early childhood settings that are responsive and affirming of their language and cultural identity.

\section{References}

AGB/MCNAIR (1992) Survey of Demand for Bilingual and Immersion Education in Māori. A report to the Ministry of Education (Wellington, AGB/McNair).

BANKS, J.A. (1996) Transformative knowledge, curriculum reform, and action, in:

J.A. BANKS (Ed.) Multicultural Education, Transformative Knowledge and Action. Historical and contemporary perspectives, pp. 335-348 (New York, Teachers College, Columbia University).

BRUNER, J. (1990) Acts of Meaning (Cambridge, MA, Harvard University Press).

CARR, M. (Ed.) (1993) Biculturalism Position Paper (Hamilton, University of Waikato, Early Childhood Curriculum Project).

CARR, M., MAY, H. \& MITCHELL, J. (1991) The development of an integrated early childhood programme, paper presented at the Proceedings of the Fifth Early Childhood Convention, Dunedin, New Zealand.

CONSEDINE, R. \& CONSEDINE, J. (2001) Healing our History. The challenge of the Treaty of Waitangi (Auckland, Penguin).

CORMACK, I. (1997) Creating an effective learning environment for Māori students, in: P. TE WHĀITI, M.MCCARTHY \& A.DURIE (Eds) Mai i Rangiātea. Māori wellbeing and development, pp. 163-169 (Auckland, Auckland University Press with Bridget Williams Books).

COXON, E., JENKINS, K., MARSHALL, J.\&MASSEY, L. (1994) The Politics of Learning and Teaching in Aotearoa-New Zealand (Palmerston North, Dunmore).

CRAWFORD, J. (1992) Hold Your Tongue: Bilingualism and the politics of ' Only' (Reading, MA, Addison-Wesley).

DALOZ, L.A. (1990) Effective Teaching and Mentoring (San Francisco, CA, JosseyBass).

DELPIT, L. (1988) The silenced dialogue: power and pedagogy in educating other people's children, Harvard Educational Review, 58(3), pp. 280-298.

DURIE, M. (2001) A framework for considering Māori educational advancement, paper presented at the Hui Taumata $\mathrm{Ma}^{-}$tauranga, Turangi/Taupo.

ELSE, A. (1997) Māori Participation \& Performance in Education. A literature review and research programme (Wellington, Ministry of Education).

FREIRE, P. \& SHOR, I. (1987) A Pedagogy for Liberation: Dialogues on transforming education (Basingstoke, Macmillan).

GIROUX, H. (1983) Theory and Resistance in Education: A pedagogy for the opposition (London, Heinemann Educational Books).

HARRIS, T. (1990) Aboriginal World View, Two-way Aboriginal Schooling: Education and cultural survival (Canberra, Aboriginal Studies Press).

HOOKS, B. (1994) Teaching to Transgress. Education as the practice of freedom (New York, Routledge).

JENKINS, K. \& PIHAMA, L. (2001) Matauranga Wahine: teaching Māori women's knowledge alongside feminism. Feminism \& Psychology, 11(3), pp. 292-303. 
JONES, A., MCCULLOCH, G., MARSHALL, J., SMITH, L.T. \& SMITH, G.H. (1990) Myths and Realities. Schooling in New Zealand (Palmerston North, Dunmore).

LAKOFF, R.T. (1990) Talking Power. The politics of language (New York, Basic Books (HarperCollins)).

LUBECK, S. (1996) Deconstructing 'child development knowledge' and 'teacher preparation', Early Childhood Research Quarterly, 11, 147-167.

MACNAUGHTON, G. (1998) Respecting difference or recycling racism? A case for reconceptualising curriculum discourses of multiculturalism and gender equity, paper presented at the Reconceptualising the Early Years of School Conference, Canberra, January.

METGE,J. (1990) Te Kohao o Te Ngira, Culture and Learning (Wellington, Learning Media).

MIKAERE,A. (1998) Taku Titiro: viewpoint rhetoric, and recrimination: striving to fulfil the bicultural commitment at Waikato Law School. He Pukenga Korero: A Journal of Mãori Studies, 3(2), pp. 4-14.

MINISTRY OF EDUCATION (1996a) Te Whāriki. He Whāriki Mātauranga mōngāa Mokopuna o Aotearoa: Early childhood curriculum (Wellington, Learning Media).

MINISTRY OF EDUCATION (1996b) Revised statement of desirable objectives and practices (DOPs) for chartered early childhood services in New Zealand. The New Zealand Education Gazette.

NODDINGS, N. (1994) An ethic of caring and its implications for instructional arrangements, in: L. STONE (Ed.) The Education Feminism Reader, pp. 171-183 (New York, Routledge).

PODMORE, V. N., MAY, H. \& MARA, D. (1998) Evaluating Early Childhood Programmes Using Te Whāriki (Wellington, New Zealand Council for Educational Research).

RAMSDEN, I. (1994a) Cultural safety. Mental Health News (Summer 94/95), p. 23.

RAMSDEN, I. (1994b) A challenge to education. Social Policy Journal of New Zealand, 3, pp. 18-25.

RAMSDEN, I.\& SPOONLEY, P. (1993) The cultural safety debate in nursing education in Aotearoa. New Zealand Annual Review of Education, 3, pp. 161-174.

RYAN, J. (1992) Aboriginal learning styles: a critical review. Language, Culture and Curriculum, 5(3), pp. 161-183.

SHADBOLT, M. (1999) From the Edge of the Sky. A memoir (Auckland, David Ling).

SIMON, J. (Ed.) (1992) Good Intentions, But ..., 3rd edn (Wellington, Quest Rapuara).

SIMON, R. (1992) Teaching against the Grain. Texts for a pedagogy of possibility (New York, Bergin \& Garvey).

SIRAJ-BLATCHFORD, I. \& SIRAJ-BLATCHFORD, J. (1999) 'Race', research and reform: the impact of the three Rs on anti-racist preschool and primary education in the UK. Race, Ethnicity and Education, 2 (1), pp. 127-148.

SMITH, G.H. (1986) Taha Maori: a Pakeha privilege. Delta, 37, pp. 11-23.

SMITH, L.T. (1999) Decolonizing Methodologies. Research and indigenous peoples (London and Dunedin, Zed Books and University of Otago Press).

SULLIVAN, K. (1993) Bicultural education in Aotearoa/New Zealand: establishing a Tauiwi side to the partnership. New Zealand Annual Review of Education, 3, pp. 191-221.

TE PUNI KŌKIRI/MINISTRY OF MĀORI DEVELOPMENT (1998a) Making Education Work for Māori. Report on consultation (Wellington, Te Puni Kōkiri/Ministry of Māori Development).

TE PUNI KŌKIRI/MINISTRY OF MĀORI DEVELOPMENT (1998b) The National Māori Language Survey. Te Mahi Rangahau Reo Māori (Wellington, Te Puni Kōkiri /Ministry of Māori Development).

WIDEEN, M., MAYER-SMITH, J.\& MOON, B. (1998) A critical analysis of the research on learning to teach: making the case for an ecological perspective. Review of Educational Research, 68(2), pp. 130-178.

ZEICHNER, K.M., GRANT, C., GAY, G., GILLETTE, M. \& VILLEGAS, A.M. (1998) A research informed vision of good practice in multicultural teacher education: design principles. Theory into Practice, 37(2), pp. 163-171. 